\title{
Silver(I) complexes of imidazolidine-2-thione and triphenylphosphines: Solid-state, solution NMR and antimicrobial activity studies
}

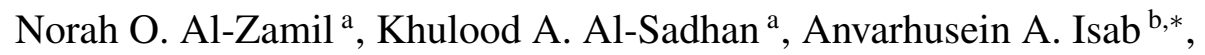 \\ Mohamed I.M. Wazeer ${ }^{\mathrm{b}}$ and Abdul Rehman A. Al-Arfaj ${ }^{\mathrm{b}}$ \\ a Department of Chemistry, Girls' College Dammam, Saudi Arabia \\ ${ }^{\mathrm{b}}$ Department of Chemistry, King Fahd University of Petroleum and Minerals, Dhahran 31261, \\ Saudi Arabia
}

\begin{abstract}
Mixed ligand complexes of $\mathrm{Ag}(\mathrm{I})$ with triphenylphosphine $\left(\mathrm{PPh}_{3}\right)$, triphenylphosphine sulfide $\left(\mathrm{SPPh}_{3}\right)$, triphenylphosphine selenide $\left(\mathrm{SePPh}_{3}\right)$ and Imidazolidine-2-thione (Imt) have been prepared. The solution as well as solid state NMR studies have been carried out to characterize these complexes. Both solid and solution NMR show the coordination via thione group on one side and $(\mathrm{S} / \mathrm{Se})$ or $\mathrm{PPh}_{3}$ on the other side. A higher antimicrobial activity is shown by $\left[\operatorname{Imt}_{A g P P h}\right] \mathrm{Cl}$ complex against gram negative Pseudomonas aeruginosa (P. aeruginosa) and Escherichia coli (E. coli) compared to the other two complexes i.e. $[\mathrm{ImtAgSPPh}] \mathrm{Cl}$ and $[\mathrm{ImtAgSePPh}] \mathrm{Cl}$.
\end{abstract}

Keywords: Silver(I) complexes, imidazolidine-2-thione, triphenylphosphines, CP MAS NMR, antimicrobial activity

\section{Introduction}

The complexation capacity of thiourea derivatives is well known [1-4] and the biological activities of thiourea complexes have been studied for different biological systems [5]. In recent years, the antifungal activity of thioureas and substituted thioureas and their $\mathrm{Ni}(\mathrm{II}), \mathrm{Cu}(\mathrm{II}), \mathrm{Pt}(\mathrm{II})$ and $\mathrm{Co}(\mathrm{III})$ complexes against phytopathogenic fungi and yeast have been studied [6-9]. Recent research has also shown that silver(I) is known to interact with selenium in the body resulting in a reduction of toxicity of both the metal ion and selenium [10,11]. Therefore, an investigation of silver complexation with seleniumcontaining ligand is important from a biological point of view.

The present report describes the solid state NMR studies of [ImtAgL]Cl (where $\mathrm{L}=\mathrm{PPh}_{3}, \mathrm{SPPh}_{3}$ or $\mathrm{SePPh}_{3}$ ) complexes by ${ }^{1} \mathrm{H},{ }^{13} \mathrm{C},{ }^{31} \mathrm{P},{ }^{77} \mathrm{Se}$ and ${ }^{109} \mathrm{Ag}$ NMR spectroscopy.

Silver complexes are known to dissociate in solution, and as such solid state NMR studies on $\mathrm{Ag}-\mathrm{S}$ and $\mathrm{Ag}-\mathrm{Se}$ containing complexes are studied and compare them with solution chemistry of these complexes [12].

\footnotetext{
*Corresponding author: Prof. A.A. Isab. Fax: +9663 860 4277; E-mail: aisab@kfupm.edu.sa.
} 


\section{Experimental}

\subsection{Materials}

$\mathrm{AgNO}_{3}, \mathrm{PPh}_{3}, \mathrm{SPPh}_{3}, \mathrm{SePPh}_{3}$ and DMSO-d $\mathrm{d}_{6}$ were obtained from Fluka Chemical Co. Imt was synthesized according to the procedure described in the literature by the addition of $\mathrm{CS}_{2}$ to ethylenediammine in ether and then heating the resulting adduct at $100^{\circ} \mathrm{C}$ for $2-3 \mathrm{hrs}$, followed by its crystallization in methanol [13,14].

\section{2. ${ }^{1} \mathrm{H}$ and ${ }^{13} \mathrm{C}$ NMR measurements}

${ }^{1} \mathrm{H}$ NMR spectra were obtained on Jeol JNM-LA 500 NMR spectrometer operating at a frequency of $500.00 \mathrm{MHz} .{ }^{13} \mathrm{C}$ NMR spectra were obtained at the frequency of $125.65 \mathrm{MHz}$ with ${ }^{1} \mathrm{H}$ broadband decoupling at $298 \mathrm{~K}$. The spectral conditions were: $32 \mathrm{k}$ data points, $0.967 \mathrm{~s}$ acquisition time, $1.00 \mathrm{or}$ 30.00 s pulse delay and $45^{\circ}$ pulse angle. ${ }^{13} \mathrm{C}$ chemical shifts relative to TMS were assigned according to the reference given in the literature [15].

\subsection{Solid state NMR studies}

Solid state cross-polarization magic-angle spinning (CPMAS) ${ }^{31} \mathrm{P}\left\{{ }^{1} \mathrm{H}\right\}$ NMR spectra were obtained a JEOL LAMBDA 500 spectrometer operating at $202.35 \mathrm{MHz}(11.74 \mathrm{~T})$, at ambient temperature of $25^{\circ} \mathrm{C}$. Samples were packed into $6 \mathrm{~mm}$ zirconium oxide rotors. The magic angle spinning rates were from $2000 \mathrm{~Hz}$ to $5000 \mathrm{~Hz}$. Contact time of $3 \mathrm{~ms}$ were used with a proton pulse width of $6 \mu \mathrm{s}$, with a recycle delay of $10 \mathrm{~s}$. Approximately 500 FID's were collected and transformed with a line broadening of $50 \mathrm{~Hz}$. Chemical shifts were referenced using an external sample of solid $\mathrm{PPh}_{3}(\delta=-8.40 \mathrm{ppm}$ from $85 \% \mathrm{H}_{3} \mathrm{PO}_{4}$ ). Natural abundance ${ }^{13} \mathrm{C}$ solid state NMR spectra were obtained at ambient temperature on the same spectrometer operating at a frequency of $125.25 \mathrm{MHz}$. Cross polarization and high power decoupling were employed. Pulse delay of $7.0 \mathrm{~s}$ and a contact time of $5.0 \mathrm{~ms}$ were used in the CPMAS experiments. Carbon chemical shifts were referenced to TMS by setting the high frequency isotropic peak of solid adamantane to $38.56 \mathrm{ppm}$. CPMAS ${ }^{77} \mathrm{Se}$ spectrum was obtained on the same instrument operating at a frequency of $95.35 \mathrm{MHz}$. The contact time of $5 \mathrm{~ms}$ with proton pulse width of $6.0 \mu \mathrm{s}$, with a recycle delay of $12 \mathrm{~s}$ were used. Sample was spun at 3 and $5 \mathrm{kHz}$ at the magic angle to determine the isotropic peak. Approximately 5000 scans were employed. ${ }^{77} \mathrm{Se}$ chemical shifts are referenced using an external ammonium selenate sample by setting its isotropic peak to $1040.2 \mathrm{ppm}$ [16] relative to liquid $\mathrm{Me}_{2} \mathrm{Se}$ at $23^{\circ} \mathrm{C}$. The ${ }^{31} \mathrm{P}$ CPMAS spectra containing spinning side-band manifolds were analyzed using a program based on Maricq and Waugh [17] and developed by Durham University, UK using an iterative method.

\subsection{Synthesis of [ImtAgPPh 3$] \mathrm{Cl}$ and related complexes}

All three compounds were prepared in a similar manner. Typically, silver chloride (1.44 g, $1 \mathrm{~mol})$ dissolved in methanol $\left(2\right.$ to $\left.3 \mathrm{~cm}^{3}\right)$ added to solution of stoichiometric quantities (1 mol) of triphenylphosphine, or triphenylphosphine sulfide, or triphenylphosphine selenide dissolved in methanol $\left(2-3 \mathrm{~cm}^{3}\right)$. The suspension was reflux for $4 \mathrm{~h}$ and 1 mol quantities of thione (Imt) was added, reflux $5 \mathrm{~h}$. The powder for each product was collected by filtration. Elemental analysis of the complexes are reported in Table 1 and the NMR chemical shifts are reported in Table 2 and Table 3 for solution and Table 4 for solid NMR respectively. 
Table 1

Characterization of [ImtAgL]Cl (where $\mathrm{L}=\mathrm{PPh}_{3}, \mathrm{SPPh}_{3}$ or $\mathrm{SePPh}_{3}$ ) complexes

\begin{tabular}{|c|c|c|c|c|c|}
\hline \multirow[t]{2}{*}{ Complex } & \multicolumn{4}{|c|}{ Found (Calcd) \% } & \multirow[t]{2}{*}{ M. Pts. $\left({ }^{\circ} \mathrm{C}\right)$} \\
\hline & $\mathrm{C}$ & $\mathrm{H}$ & $\mathrm{N}$ & $\mathrm{S}$ & \\
\hline$\left[\mathrm{ImtAgPPh}{ }_{3}\right] \mathrm{Cl}^{\mathrm{a}}$ & 48.08 (49.67) & $4.14(4.17)$ & $5.17(5.52)$ & $6.11(6.32)$ & 162 \\
\hline$[\mathrm{ImtAgSPPh}] \mathrm{Cl}$ & $45.84(46.72)$ & $4.017(3.92)$ & $5.19(6.239)$ & $11.92(11.88)$ & 150 \\
\hline$\left[\mathrm{ImtAgSePPh}{ }_{3}\right] \mathrm{Cl}$ & $42.99(43.54)$ & $3.78(3.61)$ & $5.56(4.77)$ & $5.37(5.47)$ & 168 \\
\hline
\end{tabular}

$\mathrm{a}=[24]$.

Table 2

${ }^{1} \mathrm{H}$ and ${ }^{13} \mathrm{C}$ NMR chemical shifts of $[\mathrm{ImtAgL}] \mathrm{Cl}$ (where $\mathrm{L}=\mathrm{PPh}_{3}, \mathrm{SPPh}_{3}$ or $\mathrm{SePPh}_{3}$ ) complexes in DMSO-d 6

\begin{tabular}{|c|c|c|c|c|}
\hline Species & $\mathrm{N}-\mathrm{H}$ & $\mathrm{C}-2$ & C-4 & C-5 \\
\hline Imt & 7.98 & 183.44 & 43.97 & 43.97 \\
\hline$\left.[\operatorname{ImtAgNO}]_{3}\right]^{\mathrm{a}}$ & 9.04 & 176.96 & 45.14 & 45.14 \\
\hline$[\mathrm{ImtAgPPh}] \mathrm{Cl}$ & 8.84 & 180.31 & 44.52 & 44.52 \\
\hline$\left[\mathrm{ImtAgSPPh}{ }_{3}\right] \mathrm{Cl}$ & 8.84 & 179.14 & 44.77 & 44.77 \\
\hline$\left[\mathrm{ImtAgSePPh}{ }_{3}\right] \mathrm{Cl}$ & 8.84 & 179.19 & 44.76 & 44.76 \\
\hline
\end{tabular}

$\mathrm{a}=[28]$.

Table 3

${ }^{31} \mathrm{P}$ and ${ }^{107} \mathrm{Ag}$ NMR chemical shifts of thiones and their $[\mathrm{ImtAgL}] \mathrm{Cl}$ (where $\mathrm{L}=\mathrm{PPh}_{3}, \mathrm{SPPh}_{3}$ or $\mathrm{SePPh}_{3}$ ) complexes in $\mathrm{DMSO}^{-\mathrm{d}_{6}}$

\begin{tabular}{|c|c|c|c|}
\hline Species & ${ }^{31} \mathrm{P}$ & ${ }^{107} \mathrm{Ag}$ & ${ }^{1} \mathrm{~J}\left({ }^{31} \mathrm{P}-{ }^{77} \mathrm{Se}\right)$ \\
\hline $\mathrm{PPh}_{3}$ & -9.16 & - & - \\
\hline$\left[\mathrm{AgPPh}_{3}\right] \mathrm{Cl}^{\mathrm{a}}$ & 30.38 & 639.23 & - \\
\hline$\left[\mathrm{ImtAgNO}{ }_{3}\right]$ & - & $571.03^{b}$ & - \\
\hline$[\mathrm{ImtAgPPh}] \mathrm{Cl}$ & 39.20 & 859.65 & - \\
\hline$[\mathrm{ImtAgSPPh}] \mathrm{Cl}$ & 42.94 & 690.57 & - \\
\hline$[\mathrm{ImtAgSePPh} 3] \mathrm{Cl}$ & 35.31 & 631.40 & ${ }^{1} \mathrm{~J}\left({ }^{31} \mathrm{P}-{ }^{77} \mathrm{Se}\right)=360 \mathrm{~Hz}$ \\
\hline
\end{tabular}

$\mathrm{a}=[24]$.

$\mathrm{b}=[28]$.

\subsection{Bioactivity}

Antimicrobial activity was measured as described in the literature [18]. It was evaluated by the minimum inhibitory concentration (MIC) on three microorganisms, namely Pseudomonas aeruginosa (P. aeruginosa), Fecal Streptococcus $(F S)$ and Escherichia coli (E. coli) and on group of organisms Heterotrotropic Plate Counts (HPC). HPC is a standardized means of determining the density of aerobic and facultative anaerobic heterotrophic bacteria in water/wastewater. It is a group of bacteria and not a single strain.

These bacteria/group of bacteria were isolated and cultured from domestic wastewater (Al-Khobar Wastewater Treatment Plant at Al-Azizia, Saudi Arabia) in which a variety of pathogens and other microorganisms present. Each analysis was carried out in duplicate to maintain the maximum accuracy. Dosage of reached a maximum dose of $1000 \mu \mathrm{g} / \mathrm{ml}$ was used as a stopping criterion. A stock solution of $1000 \mu \mathrm{g} / \mathrm{ml}$ was used to prepare consecutive dilution having concentration difference of $25 \mu \mathrm{g} / \mathrm{ml}$. The [ImtAgL]Cl (where $\mathrm{L}=\mathrm{PPh}_{3}, \mathrm{SPPh}_{3}$ or $\mathrm{SePPh}_{3}$ ) complexes are insoluble in water but these bioactivities are done in water as well as in DMSO for comparison (Table 5). 
Table 4

CPMAS NMR data for the complexes [ImtAgL]Cl (where $\mathrm{L}=\mathrm{PPh}_{3}, \mathrm{SPPh}_{3}$ or $\mathrm{SePPh}_{3}$ ) and the corresponding ligands ${ }^{\mathrm{a}}$

\begin{tabular}{|c|c|c|c|c|c|c|c|}
\hline Complex & Nucleus & $\delta_{\text {iso }}$ & $\sigma_{11}$ & $\sigma_{22}$ & $\sigma_{33}$ & $\Delta \sigma$ & $\eta$ \\
\hline$[\mathrm{ImtAgPPh}] \mathrm{Cl}$ & ${ }^{31} \mathrm{P}$ & 44.0 & -108 & -80 & 56 & 150 & 0.28 \\
\hline $\mathrm{PPh}_{3}{ }^{\mathrm{d}}$ & ${ }^{31} \mathrm{P}$ & -7.2 & & & & & \\
\hline$[\mathrm{ImtAgPPh} / \mathrm{Cl}$ & ${ }^{13} \mathrm{C}$ & $167.1^{\mathrm{b}}$ & & & & & \\
\hline$\left[\mathrm{ImtAgSPPh}_{3}\right] \mathrm{Cl}$ & ${ }^{31} \mathrm{P}$ & 43.9 & -109 & -78 & 51 & 145 & 0.32 \\
\hline $\mathrm{SPPh}_{3}{ }^{\mathrm{d}}$ & ${ }^{31} \mathrm{P}$ & & 46.4 & & & & \\
\hline$\left[\mathrm{ImtAgSPPh}{ }_{3}\right] \mathrm{Cl}$ & ${ }^{13} \mathrm{C} 1$ & $63.4^{\mathrm{b}}$ & & & & & \\
\hline$[\mathrm{ImtAgSePPh}] \mathrm{Cl}$ & ${ }^{31} \mathrm{P}$ & 35.6 & -100 & -55 & 48 & 127 & 0.53 \\
\hline $\mathrm{SePPh}_{3}{ }^{\mathrm{e}}$ & ${ }^{31} \mathrm{P}$ & 38.9 & -104 & -61 & 48 & & \\
\hline$\left[\mathrm{ImtAgSePPh}{ }_{3}\right] \mathrm{Cl}$ & ${ }^{13} \mathrm{C}$ & $168.1^{\mathrm{b}}$ & & & & & \\
\hline \multirow[t]{2}{*}[\mathrm{ImtAgSePPh}3]{$\mathrm{Cl}$} & ${ }^{77} \mathrm{Se}$ & i. $251.7(696 \mathrm{~Hz})^{\mathrm{c}}$ & & & & & \\
\hline & & ii. $\quad 266.8(692 \mathrm{~Hz})^{\mathrm{c}}$ & & & & & \\
\hline \multirow[t]{2}{*}{$\mathrm{SePPh}_{3}$} & ${ }^{77} \mathrm{Se}$ & i. $\quad 242.6(744 \mathrm{~Hz})^{\mathrm{c}}$ & & & & & \\
\hline & & ii. $\quad 257.5(734 \mathrm{~Hz})^{\mathrm{c}}$ & & & & & \\
\hline
\end{tabular}

${ }^{\mathrm{a}}$ Isotropic shielding, $\sigma_{\mathrm{i}}=\left(\sigma_{11}+\sigma_{22}+\sigma_{33}\right) / 3 ; \Delta \sigma=\sigma_{33}-0.5\left(\sigma_{11}+\sigma_{22}\right) ; \eta=\left(\sigma_{22}-\sigma_{11}\right) / \frac{2}{3} \Delta \sigma$.

$\mathrm{b}$ Thiocarbonyl carbon resonance;

${ }^{\mathrm{c}} \mathrm{J}_{\mathrm{P}-\mathrm{Se}}$ values; d 14; e 27.

Table 5

Antimicrobial activity for Heterotrotropic Plate Counts (HPC), Pseudomonas aeruginosa (P. aeruginosa) and Fecal Streptococcus (FS) and Escherichia coli (E. coli). MIC of various ligand and their complexes are reported in $(\mu \mathrm{g} / \mathrm{ml})$

\begin{tabular}{|c|c|c|c|c|c|c|}
\hline Test organism & $\begin{array}{c}\text { IMT } \\
\text { (water) }\end{array}$ & $\begin{array}{c}\text { IMT } \\
\text { (DMSO) }\end{array}$ & $\begin{array}{c}\mathrm{Ag}(\mathrm{IMT}) \mathrm{NO}_{3} \\
\text { (water) }\end{array}$ & $\begin{array}{c}\mathrm{Ag}(\mathrm{IMT}) \mathrm{NO}_{3} \\
\text { (DMSO) }\end{array}$ & $\begin{array}{l}\mathrm{PPh}_{3} \\
\text { (water) }\end{array}$ & $\begin{array}{c}\mathrm{PPh}_{3} \\
\text { (DMSO) }\end{array}$ \\
\hline HPC & 650 & 650 & 500 & 475 & 950 & 950 \\
\hline P. aeruginosa & 250 & 225 & 250 & 250 & 900 & 900 \\
\hline$F S$ & 300 & 300 & 400 & 350 & 875 & 850 \\
\hline E. coli & 250 & 250 & 200 & 175 & 850 & 850 \\
\hline Test organism & $\begin{array}{l}\mathrm{PPh}_{3} \mathrm{~S} \\
\text { (water) }\end{array}$ & $\begin{array}{c}\mathrm{PPh}_{3} \mathrm{~S} \\
\text { (DMSO) }\end{array}$ & $\begin{array}{l}\mathrm{PPh}_{3} \mathrm{Se} \\
\text { (water) }\end{array}$ & $\begin{array}{l}\mathrm{PPh}_{3} \mathrm{Se} \\
(\mathrm{DMSO})\end{array}$ & $\begin{array}{c}\mathrm{AgCl} \\
\text { (water) }\end{array}$ & $\begin{array}{c}\mathrm{AgCl} \\
(\mathrm{DMSO})\end{array}$ \\
\hline HPC & $>1000$ & 950 & 750 & 700 & $>1000$ & $>1000$ \\
\hline P. aeruginosa & 950 & 925 & 425 & 400 & 950 & 900 \\
\hline$F S$ & 850 & 800 & 500 & 475 & 875 & 875 \\
\hline E. coli & 800 & 800 & 250 & 250 & 750 & 700 \\
\hline Test organism & A in (water) & $\mathrm{A}$ in (DMSO) & B in (water) & $\mathrm{B}$ in (DMSO) & $\mathrm{C}$ in water & $\mathrm{C}$ in (DMSO) \\
\hline HPC & 425 & 425 & $>1000$ & $>1000$ & $>1000$ & $>1000$ \\
\hline P. aeruginosa & 300 & 300 & 950 & 925 & 950 & 950 \\
\hline$F S$ & 225 & 200 & 900 & 900 & 875 & 850 \\
\hline E. coli & 75 & 75 & 825 & 800 & 750 & 700 \\
\hline
\end{tabular}

$\mathrm{A}=\left[\mathrm{ImtAgPPh}_{3}\right] \mathrm{Cl} ; \mathrm{B}=\left[\operatorname{ImtAgSPPh}{ }_{3}\right] \mathrm{Cl} ; \mathrm{C}=\left[\mathrm{ImtAgSePPh}_{3}\right] \mathrm{Cl}$.

\section{Results and discussion}

\section{1. ${ }^{1}$ H NMR studies}

In ${ }^{1} \mathrm{H}$ NMR spectrum of the complexes, the $\mathrm{N}-\mathrm{H}$ signal of thiones became less intense upon coordination and shifted downfield by $0.7-1.0 \mathrm{ppm}$ from their positions in free ligands. The deshielding of $\mathrm{N}-\mathrm{H}$ 
proton is related to an increase of the $\pi$ electron density in the $\mathrm{C}-\mathrm{N}$ bond upon complexation [19]. The appearance of $\mathrm{N}-\mathrm{H}$ signal shows that the ligands are coordinating to silver(I) via the thione group (see Table 2).

\section{2. ${ }^{13}$ C NMR studies}

In all complexes, C-2 resonance appears upfield by 4-7 ppm compared to free ligands in accordance with the data observed for other complexes of $\mathrm{Cu}(\mathrm{I}), \mathrm{Ag}(\mathrm{I})$ and $\mathrm{Au}(\mathrm{I})$ with heterocyclic thiones [20-22]. The upfield shift is attributed to a lowering of the $>\mathrm{C}=\mathrm{S}$ bond order upon coordination and a shift of $\mathrm{N} \rightarrow \mathrm{C}$ electron density producing partial double bond character in the $\mathrm{C}-\mathrm{N}$ bond $[19,23]$. The upfield shift decreases as the number of ligands attached to silver(I) increases from one in $\left[\mathrm{LAgNO}_{3}\right]$ to two in $\left[\mathrm{AgL}_{2}\right] \mathrm{NO}_{3}$. This is because of the increase in number of electronegative groups attached to silver(I). A small shift of 1-2 ppm is observed in other carbon atoms, which shows that nitrogen atoms are not involved in coordination. The difference in shielding at C-2 is related to the strength of the metal-sulfur bond, which arises from the back donation of silver(I) to sulfur [20].

\section{3. ${ }^{31} P$ NMR studies}

The ${ }^{31} \mathrm{P}$ NMR resonance for $\mathrm{PPh}_{3}$ of free $\mathrm{PPh}_{3}$ was observed at $-9.16 \mathrm{ppm}$ (see Table 3). After complexing with $\mathrm{Ag}(\mathrm{I})$, it shifted by 40 ppm down field. Further, down field shift is observed for $\mathrm{SPPh}_{3}$ and $\mathrm{SePPh}_{3}$ as trans ligands with Imt. This down field shift is due to deshielding of P-atom with extended d orbital overlap with silver(I) [24].

\section{4. ${ }^{107}$ Ag NMR studies}

${ }^{107} \mathrm{Ag}$ NMR of $\mathrm{AgNO}_{3}$ is recorded in DMSO- $\mathrm{d}_{6}$ instead of $\mathrm{D}_{2} \mathrm{O}$, the signal is shifted by $166 \mathrm{ppm}$ showing that the ${ }^{107} \mathrm{Ag}$ chemical shift is not only sensitive to the nature of ligands but is also affected by changing the solvent. The chemical shift of $\left[\mathrm{AgPPh}_{3}\right] \mathrm{Cl}$ is $639 \mathrm{ppm}$ which is shifted by about $473 \mathrm{ppm}$ downfield after complexing with $\mathrm{PPh}_{3}$ (Table 3). When the trans ligand Imt was introduced further reduction is observed. One interesting observation from this study is the effect of $\mathrm{PPh}_{3}, \mathrm{SPPh}_{3}$ and $\mathrm{SePPh}_{3}$ on the ${ }^{107} \mathrm{Ag}$ chemical shift which increased from 859.65, 690.57 and $631.40 \mathrm{ppm}$ respectively. This trend clearly indicates that $\mathrm{PPH}_{3}$ binds more strongly to $\mathrm{Ag}(\mathrm{I})$ followed by $\mathrm{SPPh}_{3}$ and $\mathrm{SePPh}_{3}$. In terms of the basicity, $\mathrm{PPh}_{3}$ is the most basic which caused the most shift from $\left[\operatorname{ImtAgNO}{ }_{3}\right]$ to $\left[\operatorname{ImtAgPPh}{ }_{3}\right] \mathrm{Cl}$. Not so significant shift was observed when $\mathrm{SPPh}_{3}$ and $\mathrm{SePPh}_{3}$ were complexed to $\mathrm{Ag}(\mathrm{I})$.

The very large shifts in ${ }^{107} \mathrm{Ag}$ NMR in these complexes provide a clear evidence for binding of thiones to silver (I) through sulfur atom only. The nitrogen-bonded complexes usually possess a shift of around $100 \mathrm{ppm}$ in ${ }^{107} \mathrm{Ag}$ NMR [25].

\subsection{Solid state NMR studies}

The CP MAS ${ }^{31} \mathrm{P}$ spectrum for the complex $\left[\mathrm{ImtAgPPh}_{3}\right] \mathrm{Cl}$ is shown in Fig. 1 . The principal components of the chemical shift tensor were calculated from spinning side band intensities employing an iterative computer program. These are shown in Table 4 along with the chemical shift anisotropies and asymmetry parameters. The quality of the selenium spectrum was poor to reliably calculate individual chemical shift tensor values. Hence only the isotropic chemical shift values are reported in Table 4. The 


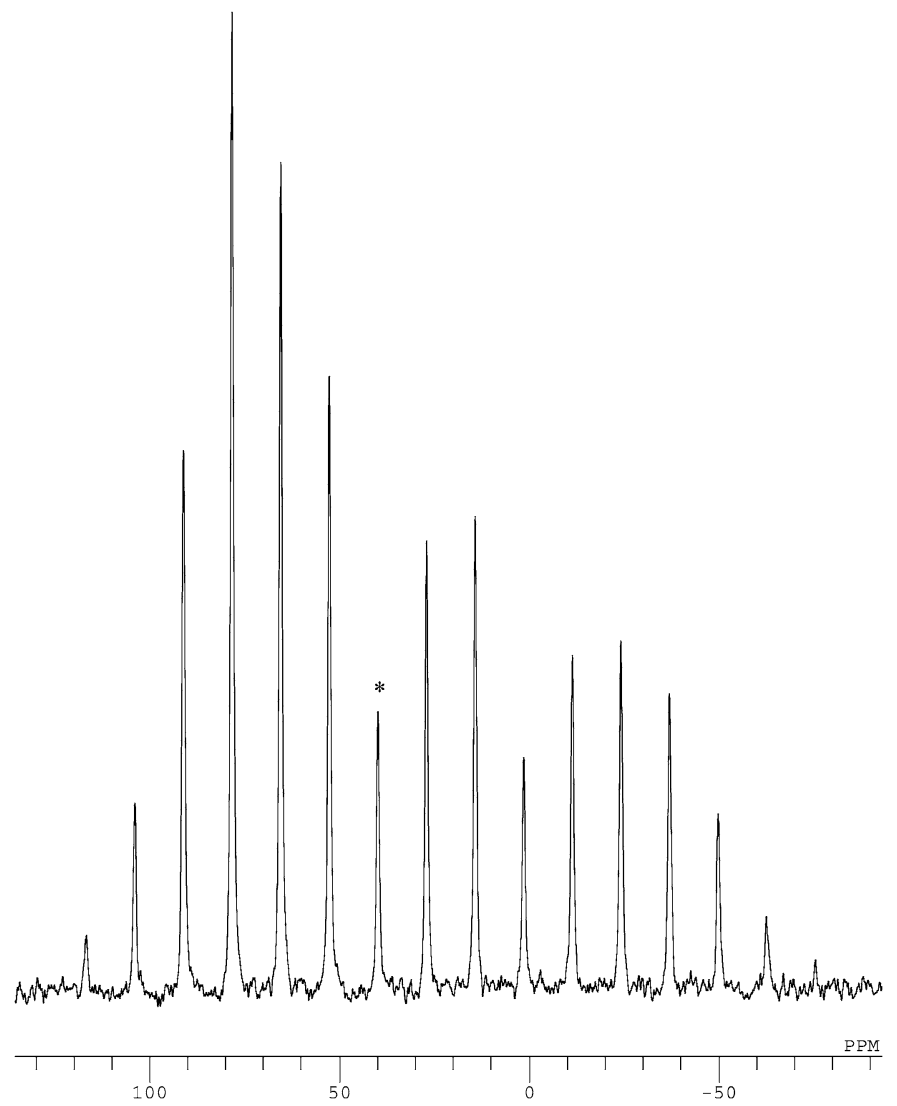

Fig. $1 .{ }^{31} \mathrm{P}$ CPMAS NMR spectrum of $[\mathrm{ImtAgPPh}] \mathrm{Cl} ; *$ denotes the isotropic peak.

thiocarbonyl carbon isotropic chemical shifts for the Imt ligand are also given in Table 4. The phosphorus nucleus in $[\mathrm{ImtAgPPh}] \mathrm{Cl}$ is deshielded by $51 \mathrm{ppm}$ relative to the free ligand, whereas in the other two complexes the phosphorus nucleus is only slightly shielded by about $3 \mathrm{ppm}$. In the phosphine complex the phosphorus is directly attached to the Ag and as such we expect the largest change. The reduction in electron density around the phosphorus nucleus leading to large de shielding can be rationalized due to the donation of phosphorus lone pair to the $\mathrm{Ag}$ atom. In $\left[\mathrm{ImtAgSePPh}{ }_{3}\right] \mathrm{Cl} \mathrm{complex}$ the $\sigma_{11}$ and $\sigma_{22}$ components are shielded relative to the $\mathrm{PPh}_{3}$ Se ligand. Therefore, it can be postulated that the meta-ligand vector is oriented perpendicular to these two components, as the shielding effect is maximal in the direction perpendicular to this vector [26]. The ${ }^{77} \mathrm{Se}$ spectrum of $[\mathrm{ImtAgSePPh} 3] \mathrm{Cl}$ showed two isotropic peaks along with $\mathrm{J}$ coupling to phosphorus. The ligand $\mathrm{PPh}_{3} \mathrm{Se}$ also showed [27] two isotropic peaks indicating two molecules in a unit cell. However, only one phosphorus environment was observed in the free ligand as well as in the complex. The selenium resonance is deshielded by about 9 ppm on complexation. The carbon resonances of the thiocarbonyl carbons in the complexes are shielded by about 12 to $17 \mathrm{ppm}$ relative to the free ligand [28].

\subsection{Bioactivity studies}

The results of the bioactivity studies are given in Table 5. No major difference in antimicrobial activity was observed between free ligand Imt and its complex with $\mathrm{AgNO}_{3}$. The phosphine ligands 
also show very little activity. However, after complexing with trans phosphine to the $\mathrm{Ag}(\operatorname{Imt}) \mathrm{Cl}$ complex, the antimicrobial activity has improved. It should be noted that the other two complexes namely

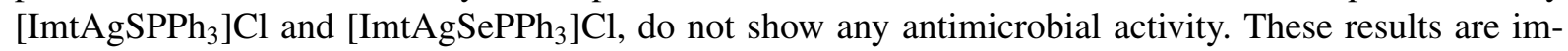
portant because thione ligand can be in equilibrium with its thiol form, so these data can be related to thiol containing complexes [18] as well.

\section{Acknowledgements}

This research work was supported by the KFUPM Research Committee under project number CY/NMR STUDY/277.

\section{References}

[1] K.R. Koch, Coord. Chem. Rev. 216-217 (2001), 473.

[2] P.D. Arkivos, Coord. Chem. Rev. 213 (2001), 181.

[3] E. Rodríguez-Fernández, J.L. Manzano, J.J. Benito, R. Hermosa, E. Monte and J.J. Criado, J. Inor. Biochem. 99 (2005), 1558.

[4] J.A. García-Vázquez, A. Sousa-Pedrares, M. Carabel, J. Romero and A. Sousa, Polyhedron 24 (2005), 2043.

[5] H. Arslan, U. Flörke and N. Külcü, Turk. J. Chem. 28 (2004), 673.

[6] J.J. Criado, E. Rodríguez-Fernández, E. García, M.R. Hermosa and E. Monte, J. Inorg. Biochem. 69 (1998), 113.

[7] E. Rodríguez-Fernández, E. García, M.R. Hermosa, A. Jiménez-Sánchez, M. Mar-Sánchez, E. Monte and J.J. Criado, J. Inorg. Biochem. 75 (1999), 181.

[8] R. del Campo, J.J. Criado, E. García, M.R. Hermosa, A. Jimenez-Sanchez, J.L. Manzano, E. Monte, E. RodríguezFernández and F. Sanz, J. Inorg. Biochem. 89 (2002), 74.

[9] R. del Campo, J.J. Criado, R. Gheorghe, F.J. González, M.R. Hermosa, F. Sanz, J.L. Manzano, E. Monte and E. RodríguezFernández, J. Inorg. Biochem. 98 (2004), 1307.

[10] C. Sasakura and K.T. Suzuki, J. Inorg. Biochem. 71 (1998), 159.

[11] C.J. Dollard and A.L. Tappel, J. Inorg. Biochem. 28 (1986), 13.

[12] S. Ahmad, A.A. Isab and W. Ashraf, Inorg. Chem. Comm. 5 (2002), 816.

[13] G.D. Thorn, Can. J. Chem. 33 (1955), 1278.

[14] M.I.M. Wazeer, A.A. Isab and A. El-Rayyes, Spectroscopy 18 (2004), 113 (and references therein).

[15] M.N. Akhtar, A.A. Isab, A.R. Al-Arfaj and M.S. Hussain, Polyhedron 16 (1997), 125 (and references therein).

[16] M.J. Collins, C.I. Ratcliff and J.A. Ripmeester, J. Magn. Reson. 68 (1986), 172.

[17] J. Maricq and J. Waugh, Chem. Soc. 70 (1979), 3300.

[18] K. Nomiya, A. Yoshizawa, K. Tsukagoshi, N.C. Kasuga, S. Hirakawa and J. Watanabe, J. Inorg. Biochem. 95 (2003), 208.

[19] Z. Popovic, G. Pavlovic, D. Matkovic-Calogovic, Z. Soldin, M. Rajic, D. Vikic-Topic and D. Kovacek, Inorg. Chim. Acta 306 (2000), 142.

[20] J.S. Casas, E.G. Martinez, A. Sanchez, A.S. Gonzalez, J. Sordo, U. Casellato and R. Graziani, Inorg. Chim. Acta 241 (1996), 117.

[21] A.A. Isab and C.F. Shaw III, J. Inorg. Biochem. 38 (1990), 95.

[22] A.A. Isab and M.I.M. Wazeer, J. Coord. Chem. $\mathbf{5 8}$ (2005), 529.

[23] U. Bierbach, T.W. Hambly and N. Farrell, Inorg. Chem. 37 (1998), 708.

[24] M.S. Hussain, M.L. Hossain and A.R. Al-Arfaj, Trans. Met. Chem. 15 (1990), 120.

[25] S. Ahmad, A.A. Isab and H.P. Perzanowski, Transition Met. Chem. 27 (2002), 782.

[26] A. Riviera and P.D. Ellis, Inorg. Chem. 31 (1992), 2096.

[27] G. Grossmann, M.J. Potrzebowski, U. Fleischer, K. Kriger, O.L. Malkina and W. Ciesielski, Solid State NMR 13 (1998), 71.

[28] A.A. Isab, S. Ahmad and M. Arab, Polyhedron 21 (2002), 1267. 


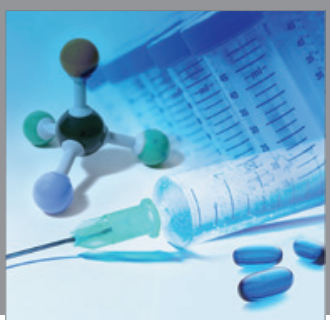

International Journal of

Medicinal Chemistry

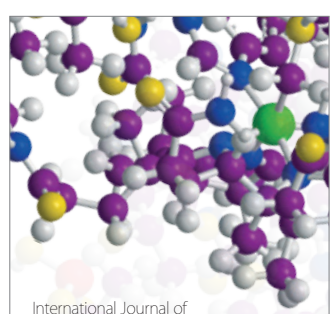

Carbohydrate Chemistry

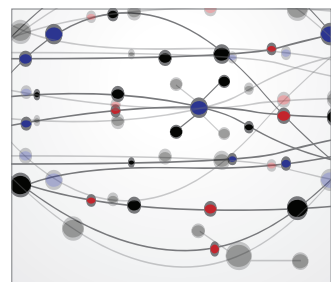

The Scientific World Journal
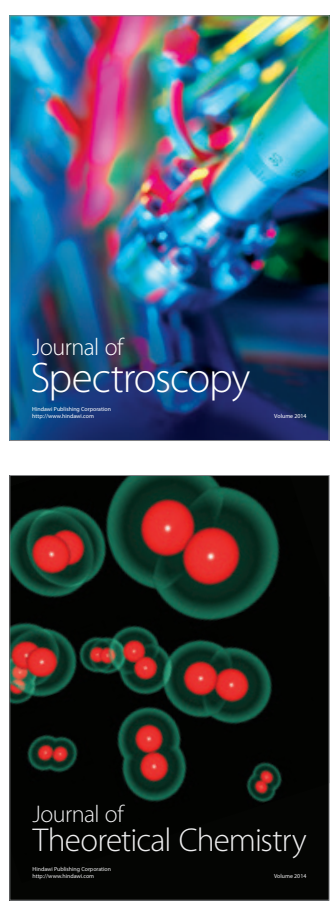
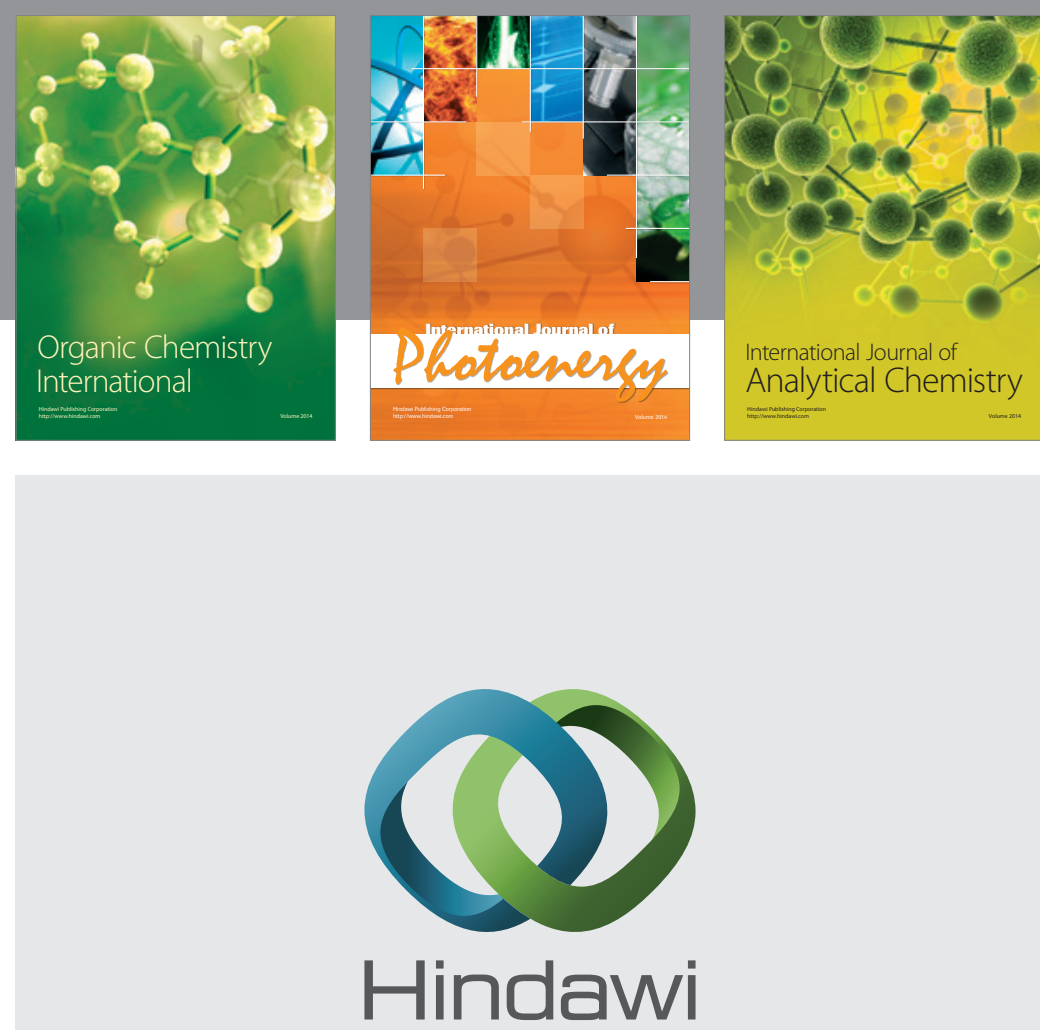

Submit your manuscripts at

http://www.hindawi.com
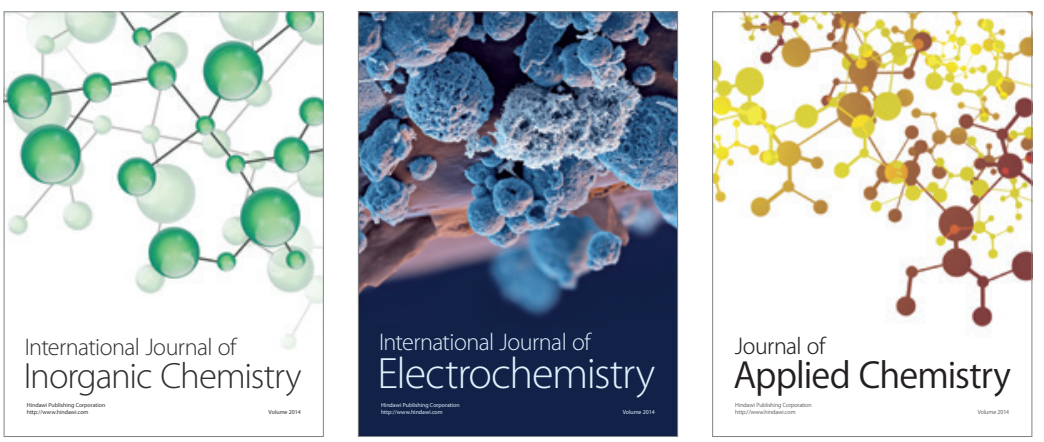

Journal of

Applied Chemistry
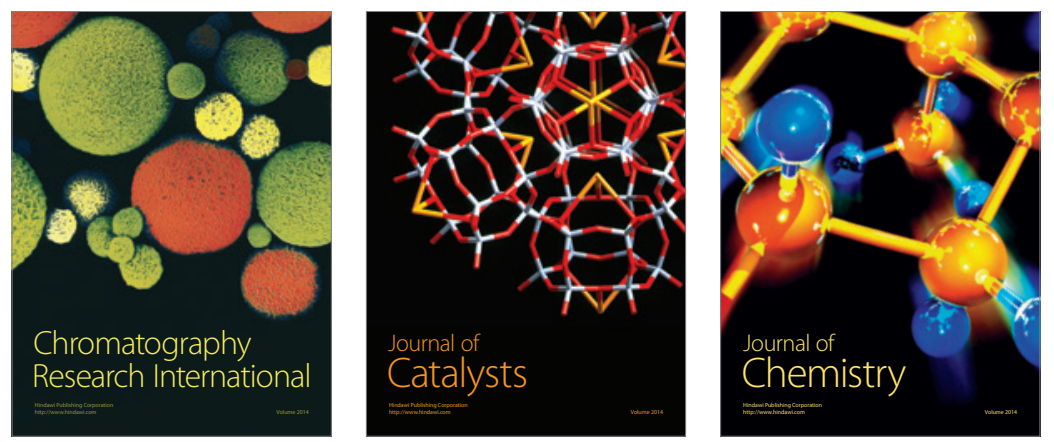
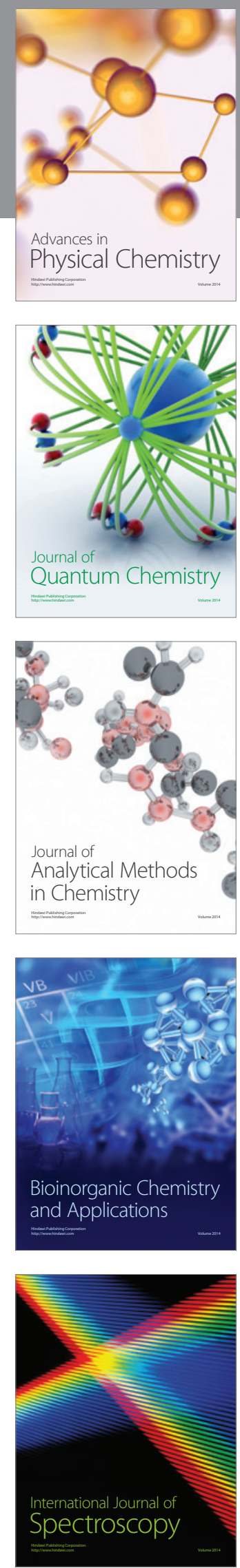